\title{
Особливості уродинаміки нижніх сечових шляхів у хворих за ідіопатичного гіперактивного сечового міхура
}

\author{
Ю. М. Дехтяр, Ф. І. Костев, О. І. Яцина, Р. В. Савчук, К. А. Залива
}

Одеський національний медичний університет

\section{Peculiarities of urodynamics of lower urinary ways in patients with idiopathic hyperactive bladder}

\author{
Yu. M. Dekhtyar, F. I. Kostev, O. I. Yatsyna, R. V. Savchuk, K. A. Zalyva
}

Odessa National Medical University

\section{Реферат}

Вступ. Гіперактивність сечового міхура (ГАСМ) - тяжкий розлад сечовипускання, що виявляють майже у $17 \%$ населення віком старше 40 років, 3 них 56\% - жінок, 44\% - чоловіків.

Мета. Визначення частоти і клінічного значення окремих уродинамічних симптомів, що виявляють за результатами комплексного обстеження хворих за ідіопатичної ГАСМ (ІГАСМ).

Матеріали і методи. Комбіноване уродинамічне дослідження проведене у 137 хворих за ІГАСМ (105 жінок, 32 чоловіків).

Результати. Імперативний характер сечовипускання у хворих за ІГАСМ зумовлює зменшення максимальної цистометричної місткості - у 75,9\% хворих, зниження порогу чутливості сечового міхура (СМ) у 70,8\%, гіперактивності м'яза - випорожнювача СМ (МВСМ) у 35,8\%, комплаєнтності - у 43,1\%, нестабільності сечівника - у 24,8\%.

Висновки. Зменшення здатності СМ до накопичення й утримання сечі за нормального або низького внутрішньоміхурового тиску та часте поєднання нестабільності СМ з ознаками обструкції сечовипускання є основними особливостями порушення уродинаміки нижніх сечових шляхів (НСШ) у хворих за ІГАСМ.

Ключові слова: гіперактивний сечовий міхур; уродинаміка; нижні сечові шляхи.

\section{Abstract}

Introduction. Hyperactivity of the bladder $(\mathrm{HAB})$ - severe disorder of urination, which is revealed in almost $17 \%$ of population, ageing more than $40 \mathrm{yrs}$, of them $56 \%$ - women, $44 \%$ - men.

Objective. Determination of rate and clinical significance of some urodynamic symptoms, which are revealed in accordance to results of complex examination in idiopathic HAB.

Materials and methods. Combined urodynamic investigation was conducted in 137 patients, suffering HAB (105 women, 32 men).

Results. Imperative character of urination in patients with HAB causes reduction of maximal cystometric capacity - in $75.9 \%$ of patients, lowering of the bladder sensitivity threshold in $70.8 \%$, the bladder detrusor muscle hyperactivity - in $35,8 \%$, compliance - in $43.1 \%$, ureteric instability - in $24.8 \%$.

Conclusion. Reduction of the bladder capacity of gathering and withholding of urine in normal or low intrabladder pressure and frequent combination of the bladder nonstability with signs of the urination obstruction constitutes the main peculiarities of disorder of the lower urinary ways urination in patients, suffering HAB.

Keywords: hyperactive bladder; urodynamics; lower urinary ways.

Гіперактивність сечового міхура (ГАСМ) - тяжкий розлад сечовипускання, що виявляють не менше ніж у 17\% населення віком старше 40 років, у тому числі 56\% жінок і 44\% чоловіків [1]. Після 65 років частота цих симптомів збільшується до 30\%, після 70 років - до 40\%. ГАСМ - це описовий термін, що визначає симптомокомплекс, при формуванні якого в пацієнта з'являються досить сильні позиви до сечовипускання (ургентність), з наявністю або без ургентного нетримання сечі (НС), як правило, супроводжуються частим сечовипусканням і ноктурією, за відсутності явних патологічних змін у самому СМ та порушень хімічного складу сечі [2]. Частішання сечовипускання - це скарги пацієнтів на занадто часті позиви протягом дня, ноктурія - скарги пацієнтів на необхідність прокидатися в нічний час більше одного разу для спорожнення СМ. Часте сечовипускання і ноктурія можуть не супроводжуватися ургентним НС [3]. Як правило, у таких хворих порушується сон, виникають депресивні й тривожні розлади. В основі синдрому ГАСМ лежить гіперактивність МВСМ - уродинамічне поняття, що означає мимовільні спонтанні або спровоковані скорочення МВСМ під час фази наповнення СМ. Виділяють дві основні форми гіперактивності МВСМ: нейрогенну та ідіопатичну. Нейрогенні причини ГАСМ - це порушення іннервації СМ внаслідок неврологічних захворювань і пошкоджень, зокрема супраспінальні (хвороба Паркінсона, розсіяний склероз, хвороба Альцгеймера, інсульт тощо) і супрасакральні (остеохондроз, спондилоартроз хребта, грижа Шморля, мієломенінгоцеле тощо) пошкодження. До факторів ризику ідіопатичної (не нейрогенної) гіперактивності МВСМ належать вікові зміни, інфравезикальна обструкція, міогенні та анатомічні зміни міхурово-уретрального сегмента, а також сенсорні порушення [2,3].

Діагностика дисфункції НСШ у хворих за ІГАСМ включає аналіз скарг, даних анамнезу, неврологічного й урологічного обстеження, а також додаткові методи обстеження, серед яких основне місце посідає уродинамічне дослідження. Питання про клінічне значення уродинамічних досліджень у діагностиці різних форм розладів 
сечовипускання обговорюються. Ми вважаємо, що показаннями до проведення уродинамічного дослідження є: відсутність ефекту емпірично призначеної терапії, плановане хірургічне втручання (наприклад, за стресового НС), супутні неврологічні захворювання [4].

Метою дослідження був аналіз частоти і клінічного значення окремих уродинамічних симптомів, виявлених за результатами комплексного уродинамічного дослідження у хворих за ІГАСМ.

\section{Матеріали і методи дослідження}

Комбіноване уродинамічне дослідження (урофлоуметрія - УФМ, профілометрія сечівника, цистометрія наповнення і випорожнення СМ, електроміографія - ЕМГ тазового дна) проведене у 137 хворих за ІГАСМ (105 жінок, 32 чоловіків). Дослідження проводили на уродинамічній установці «Delphis KT» (Laborie, Канада) відповідно до рекомендацій Комітету зі стандартизації Міжнародного товариства з НС. Дослідження включало урофлоуметрію, цистометрію наповнення, профілометрію сечівника, дослідження «тиск-поток».

Усім пацієнтам проведене урологічне, гінекологічне, неврологічне обстеження для виключення соматичних захворювань, здатних спричинити ГАСМ. Також в усіх пацієнтів організована реєстрація ритму спонтанного сечовипускання шляхом заповнення щоденника сечовипускання протягом 3 діб у звичних домашніх умовах. Пацієнт заповнював щоденник сечовипускання, починаючи з моменту пробудження і до моменту пробудження на наступну добу. При цьому пацієнти відзначали час відходу до сну, що давало можливість визначити кількість сечовипускань, ургентних позивів і епізодів НС протягом доби. Хворі детально проінструктовані щодо правильного заповнення щоденника сечовипускання, рекомендовано не змінювати звичайний розпорядок дня і питний режим.

Біоелектричну активність м'язової системи тазового дна визначали за даними комп'ютерної ЕМГ на 2-канальному комп'ютерному електроміографі «NeuroTrac ${ }^{\text {тм }}$ MyoPlus4».

\section{Результати}

При дослідженні функції СМ у фазу накопичення за методом ретроградної цистотонометрії (ЦТМ) у 104 (75,9\%) хворих за ІГАСМ відзначали зменшення максимальної цистометричної місткості, у 97 (70,8\%) - зниження порогу чутливості СМ, у 59 (43,1\%) - комплаєнтності, у 49 (35,8\%) - основною ознакою дисфункції була інтермітуюча внутрішньоміхурова гіпертензія протягом усього періоду заповнення СМ внаслідок спонтанного скорочення ВВСМ. Їх кількість в одну фазу накопичення становила від 1 до 12. Якщо за мінімального за силою скорочення внутрішньоміхуровий тиск підвищувався до 15 см вод. ст., за максимального - до 42 см вод. ст., тобто до значень мікційного.

Показники ЦТМ не відображають справжню анатомічну місткість СМ, проте цей уродинамічний показник, як правило, перевищував об'єм сечовипускання, що фіксували хворі в щоденнику. Нормальні показники ЦТМ виявлені у 22 (16,0\%) хворих. У той же час ми не вважаємо за обов'язкове виключення цих пацієнтів з групи тих, кому показане лікування з приводу ІГАСМ. У 34 (24,8\%) хворих відзначали нестабільність сечівника, у 47 (34,3\%) - функціональну інфравезикальну обструкцію, у 69 (44,5\%) - сфінктерів, у 55 (40,1\%) - зменшення функціональної довжини сечівника, у 37 (27\%) - цисталгію під час уродинамічного дослідження, у 10 (7,3\%) - псевдодиссинергію, у 31 (22,6\%) - нетримання сечі під час дослідження

Порівнюючи результати ЦТМ 3 клінічними даними, ми відзначили дисоціацію порогу чутливості й рефлекторності, тобто позиви на сечовипускання, цисталгія, відчуття переповнення СМ з'являлися за низького внутрішньоміхурового тиску. Підвищена чутливість і збудливість СМ на тлі нормотонічності, імовірно, пов'язані з підвищеною чутливістю слизової оболонки сечівника і трикутника СМ до потрапляння навіть мінімальної порції сечі. Таким чином, дисоціація порогу чутливості й рефлекторності МВСМ характерна для ІГАСМ.

Аналізуючи дані при реєстрації спонтанного сечовипускання, слід відзначити, що у хворих за нормальної рефлекторної збудливості СМ і частково за гіпорефлексії сечовипускання частіше було пришвидшеним. Ефективний об'єм СМ істотно не змінювався. Це пояснюємо тим, що сечовипускання тісно пов'язане з чутливістю СМ, це визначає характер рефлекторної реакції. Тому чутливість СМ суттево впливає на частоту сечовипускання. Крім іншого, гіперчутливість СМ у цих хворих може бути причиною імперативних позивів та імперативного НС. Припущення про нормальну рефлекторну активність СМ підтверджується реєстрацією ритму сечовипускання з окремими нормальними або великими порціями.

Функція сфінктерного апарату, як правило, також порушується. За результатами профілометрії сечівника, у 61 (44,5\%) хворого за ІГАСМ величина максимального тиску в ньому не перевищувала 30 см вод. ст., що свідчило про наявність недостатності сфінктера сечівника. У 55 (40,1\%) хворих виявлене зменшення функціональної довжини сечівника; у 34 (24,8\%) - коливання максимального внутрішньоуретрального тиску при статичному положенні датчика протягом 5 - 10 хв, амплітудою 15 - 20 см вод. ст., що визначено нами як нестабільність сечівника.

За результатами УФМ спостерігали 3 вірогідних варіанти випорожнення СМ: у 56 (40,1\%) хворих - нормальне сечовипускання, у 34 (24,8\%) - стрімке, у 47 (34,3\%) - обструктивне; у 24 (17,5\%) - переривчасте сечовипускання.

У більшості хворих, судячи по результатах ретроградної цистометрії, безпосередньо перед сечовипусканням відзначали підвищення тонусу МВСМ. Відтак є підстави сподіватися на «стрімке» сечовипускання (за умови пропорційного тонусу збільшення ефективного діаметра сечівника). Проте це спостерігали тільки у 47 хворих, у решти його відсутність, імовірно, пов'язана з непропорційним відкриттям сфінктера. В одних хворих (за мінімального неповного розслаблення сфінктера під час мікціi) відзначали нормальне сечовипускання, в інших обструктивне.

Дослідження функціі СМ у фазі його спорожнення за методами УФМ та ЕМГ м'яза-замикача відхідника підтвердили зв'язок обструктивного сечовипускання $з$ неповним розслабленням м'язів сечівника від впли- 
ву сфінктера: спорожнення СМ відбувалося на тлі досить високої його електричної активності. За даними уродинамічного дослідження це проявлялося реєстрацією «спалахів» скорочувальної активності посмугових м'язів сфінктера сечівника і м'язів тазового дна, що утруднювало, а нерідко повністю припиняло потік сечі.

При детальному оцінюванні характеру сечовипускання за допомогою дослідження «тиск - потік» у хворих $з$ ознаками обструктивного сечовипускання і нестабільності сечівника під час сечовипускання зниження тиску в сечівнику не відбувалося, що, напевно, й зумовлювало інфравезикальну обструкцію. У хворих з ознаками нестабільності МВСМ реєстрували спонтанні підвищення і зниження тиску і в момент мікції, що також могло зумовлювати поєднання полакіурії, імперативної інконтиненції та обструктивного сечовипускання.

За результатами цистометрії та сфінктерної ЕМГ можна судити про координованість функції МВСМ і зовнішнього м'яза-замикача сечівника. У 17,8\% хворих за ГАСМ симптоми дисфункції м'язів промежини і сфінктерного апарату за даними ЕМГ не виявляли. Під час фази накопичення сечі в СМ у цих пацієнтів підвищувалася активність сфінктерів НСШ з максимальною вираженістю ЕМГ-сигналів у момент появи першого позиву на сечовипускання. У період евакуаторної фази сечовипускання, при довільному скороченні МВСМ спостерігали розслаблення посмугових м'язів сечівника, що відображалося на сфінктерній ЕМГ-кривій зникненням електричних сигналів. За даними ЕМГ, проведеної по двох каналах оберненого зв'язку 3 визначенням динаміки внутрішньоміхурового тиску, у 35 хворих за ГАСМ сфінктери СМ та відхідника перебувають у різних станах, тобто існують істотні відмінності рівня електричної активності цих сфінктерів.

\section{Обговорення}

Уже при аналізі добового ритму сечовипускання у хворих за ІГАСМ відзначено, що незважаючи на різноманітність клінічних проявів, у більшості хворих однотипні порушення резервуарної функції СМ частіше пов'язані з гіперактивністю МВСМ. Це зменшення середнього ефективного об'єму СМ, часті позиви до сечовипускання, наявність імперативного сечовипускання, епізодів НС. В оцінюванні порушення сечовипускання, на нашу думку, важливу роль відіграє реєстрація ритму спонтанного сечовипускання. Це єдиний об'єктивний метод неінструментального визначення здатності СМ до накопичення й утримання сечі - багаторазова неінструментальна ЦТМ, що дозволяє оцінити поріг рефлекторної збудливості СМ. Комплексне уродинамічне дослідження доповнює дані клінічного дослідження. Отримані дані слід зіставляти з вираженістю клінічних симптомів. Діагностувати той чи інший вид порушення сечовипускання у більшості хворих можна без застосування інвазивних методів уродинамічного дослідження. I лише в деяких ситуаціях, у хворих за складних порушень сечовипускання (наприклад, при поєднанні НС й обструктивного сечовипускання) встановлення діагнозу потребує проведення комплексного уродинамічного дослідження.

Характеризуючи в цілому особливості порушення уродинаміки НСШ при ІГАСМ, слід наголосити, що зменшення здатності СМ до накопичення й утримання сечі за нормального або низького внутрішньоміхурового тиску $€$ основною причиною нестабільності СМ. Вона визначає наполегливу потребу випорожняти СМ одразу після появи позиву. Іншою особливістю є часте поєднання нестабільності СМ з ознаками обструктивного сечовипускання, що найчастіше зумовлене первинною обструкцією шийки СМ. Такі клінічні стани можуть бути спричинені різним, часом парадоксальним, поєднанням уродинамічних симптомів, що потрібно мати на увазі під час обстеження таких пацієнтів.

Аналізуючи велику кількість варіантів змін уродинаміки, слід звернути увагу, що в кожного хворого, за даними вивчення ритму спонтанного сечовипускання, спостерігають різні значення ефективного об'єму СМ. Ці дані, на перший погляд, не відповідають результатам цистотонометрії, що, по суті, й визначає необхідність проведення уродинамічних досліджень для верифікації дисфункцій НСШ. Проте середній ефективний об'єм СМ зменшений, отже можна зробити висновок, що більшість хворих за ІГАСМ, незалежно від іiі форми, намагаються випорожнити СМ після появи першого імперативного позиву на сечовипускання (або не чекаючи імперативного позиву), значно рідше сечовипускання відбувається відповідно до справжнього стану рефлекторної збудливості СМ. На нашу думку, виражена гіперчутливість СМ у більшості хворих й особливості вольового контролю визначають клінічні прояви ІГАСМ.

\section{Висновки}

1. У більшості хворих за ІГАСМ виявляють однотипні порушення резервуарної функції СМ, частіше пов'язані зі зменшенням його середнього ефективного об'єму, частими позивами до сечовипускання, наявністю імперативного сечовипускання, епізодів НС.

2. Імперативне сечовипускання у хворих за ІГАСМ, зумовленого гіперактивністю та гіперчутливістю СМ залежно від вираженості порушення інтегративної функції НСШ, зумовлює зниження максимальної цистометричної місткості у 75,9\% хворих, зниження порогу чутливості СМ - у 70,8\%, гіперактивності МВСМ - у 35,8\%, комплаєнтності - у 43,1\%, нестабільність сечівника - у $24,8 \%$.

3. Зменшення здатності СМ до накопичення й утримання сечі за нормального або низького внутрішньоміхурового тиску та часте поєднання нестабільності СМ 3 ознаками обструктивного сечовипускання є основними особливостями порушення уродинаміки НСШ у хворих за ІГАСМ.

\section{References}

1. Gormley EA, Lightner DJ, Burgio KL. Diagnosis and treatment of overactive bladder (non-neurogenic) in adults: AUA/SUFU Guideline. 2012 May. American Urological Association. J Urology. 2012 Dec;188(6) suppl:2455-63. doi: 10.1016/j.juro.2012.09.079. Epub 2012 Oct 24.

2. Thüroff JA, Abrams P, Andersson KE. EAU guidelines on urinary incontinence. Eur Urol. 2011 Mar;59(3):387-400. doi: 10.1016/j.eururo.2010.11.021. Epub 2010 Nov 24.

3. Blaivas J, Chancellor M. Atlas of urodynamics. NY Blackwell Pull. 2007. $256 \mathrm{p}$.

4. Dekhtiar YM, Kostyev FI, Rudenko OV, Kuznietsov DO. Urodynamic patterns of the idiopathic overactive bladder. Science Journal of Clinical Medicine. 2017;6(5):74-9. doi: 10.11648/j.sjcm.20170605.12. 